In: Lehtimäki, M. Karttunen, L. \& Mäkelä, M. (eds) Narrative, Interrupted. The plotless, the disturbing and the trivial in literature. 24-41. Berlin: De Gruyter.

Matti Hyvärinen

(University of Tampere)

D) This document has been downloaded from TamPub.uta.fi The Institutional Repository of University of Tampere

\title{
Resistance to Plot and Uneven Narrativity: A Journey from “A Boring Story” to The Rings of
}

\section{Saturn}

In November 2006, during an academic visit to Atlantic Canada, Peggy Heller, a political theorist whose manuscript of a dissertation I was about to discuss there, gave me W.G. Sebald's small and unsettling book Campo Santo (2005) to read during my intercontinental flight home. Unfortunately, as my memory is not as exact as Sebald's, I am unable to recollect all the events, encounters and sensations of the journey with the same exactitude as Sebald does throughout his work, nevertheless the inimitable voice of the essays did not leave me but insisted on further investigations into Sebald's work. Travelogue is the dominant genre in Sebald's oeuvre, a choice that posits his writing at first sight within non-fiction while in fact opening doors to traffic between fiction and non-fiction, narrative and essay. Parts of his work—-for example Emigrants (1993) and Campo Santo—may be read without much trouble as non-fiction, whereas distinct fictional elements prevail in Austerlitz (2001). A characteristic, even peculiar feature in his novels and essays is the documentary use of images_-photographs, paintings, maps_-including his most fictional works. ${ }^{1}$

Reading Sebald helps me, as I hope, to explore and elaborate further a slightly confusing theoretical dilemma: How does one currently understand and recognize narrativity? For a long time now, narrative theorists have reasoned that 'narrative' is not a categorical all-or-nothing issue but that we rather should approach it in a more-or-less manner (e.g. Abbott; Fludernik; Herman). Unfortunately, this argument of gradients or degree of narrativity does not solve all of the potential problems, as I endeavor to demonstrate in this article. My awareness of this problem of uneven narrativity was originally triggered by Pekka Tammi who, in his splendidly provocative essay “Against Narrative ('A Boring Story'),” analyzes Anton Chekhov’s short story in terms of its 'weak narrativity.' Tammi draws his notion of weak narrativity from Brian McHale (165), who says that “[w]eak narrativity involves...telling stories 'poorly,' distractedly, with much irrelevance and

\footnotetext{
${ }^{1}$ Below, I maintain that Sebald's topic in The Rings of Saturn is human destruction. From page five onwards, for example, he praises the work of his two recently deceased colleagues. I am muted by the harsh extra-literary fact that my good friend and colleague Kathleen Margaret Heller, born in Toronto in 1956, died, after a short struggle against an aggressive illness, on 20 June 2011, before I was finally able to finish this article that I had started to prepare-long before knowing anything about her illness.
} 
indeterminacy, in such a way as to evoke narrative coherence while at the same time withholding commitment to it and undermining confidence in it; in short, having one's cake and eating it too" (quoted in Tammi 30). To reveal my cards already, I will ask, in what follows, whether this characterization defines all ‘weak narrativity’ or rather one particular category of non-prototypical narrativity.

High and dense narrativity, for McHale and Tammi, would obviously signify telling stories well, economically and with enough determinacy and coherence. Tammi surveys a plethora of definitions of narrative in his article prior to his conclusion: "Theorists...persist in their view of narrative as an instrument for coming to terms with time, process, and change” (31). Tammi proceeds then to a resourceful reading of “A Boring Story,” showing all kinds of indeterminacies and oscillations between iterative and singular narrations, and points out the readers' difficulties in grasping the actual sequences of events in the story. Unquestionably the short story is alarmingly static in places and concentrates on enduring, painful states of affairs without the prominence of a clear and dramatic plotline. This is all true, but in what terms does this indicate 'weak narrativity'?

Monika Fludernik proposed, in her path-breaking Towards a 'Natural' Narratology, "the redefinition of narrativity qua experientiality without the necessity of any actantial groundwork. In [her] model there can therefore be narratives without plot, but there cannot be any narratives without a human (anthropomorphic) experiencer of some sort at some narrative level” (13). If we endorse experientiality as the key element of narrativity, “A Boring Story” is of course a prime example of high narrativity. The old professor's awareness of being incurably ill, his experience of dissolved communion with his family, as well as his irreparable feeling of the lost meaning of his academic work dominate the short story instead of a flow of temporally well-arranged events. Paradoxically then, I can largely agree upon the qualities of the short story outlined by Tammi, can recognize similar features in close reading of the text, but depending on our obviously different version of narrativity, we can arrive at totally contrasting results about the level of narrativity in the story.

Perhaps, then, both the perspective of classical narratology, focusing on the sequence of events, and Fludernik’s strictly experiential notion are still somehow one-sided. Partly in order to alleviate this dilemma, David Herman suggests in his Basic Elements of Narrative a more complex model that attempts to strike a reasoned balance between these two positions (9-22). It is worth noticing that Herman's conceptual strategy differs from most of the traditional 'bare minimum' definitions discussed by Tammi even on another level, since his purpose is to mark out the 
prototypical core of narrativity. Let me define 'prototypical narrative' as one that most people, in most cases would easily recognize as a narrative. By resorting to folk knowledge, such an understanding is both historically changing and culturally shaped. Following Fludernik's and Herman's thought, there is not too much to be learned of the play with such extremely marginal narratives as in "The king died and then the queen dies of sorrow” (Forster 60).

However, reading “A Boring Story” with the help of Herman’s prototype offers new contradictions. To begin with, narratives are for Herman "situated” presentations (14). It is equally clear that the novel is a part of Chekhov's artistic work from a particular period, and that the old professor's narration is deeply situated within the confines of his conundrum. On the second level, a prototypical narrative "cues interpreters to draw inferences about a structured time course of particularized events.” At this point, we face actual resistance caused by the iterative and pseudoiterative narration, and yet there is a narrow thread of "particularized" events to be detected and "cued" by the text. The third element of world-making and world-disruption, in contrast, is extensively elaborated in the short story. The story exhibits a dramatic structure of before and after: before the professor had a magnificent career, before he knew personally all the prominent scholars in Russia and was celebrated all over Europe, before he enjoyed lecturing and flourished in his work. 'Now,' since his illness, since all the excruciating changes in his life, this successful world has perished. On the fourth and final level, Herman picks up the element of experientiality, 'how it feels,' maintaining that narrative representation “also conveys the experience of living through this storyworld-in-flux, highlighting the pressure of the events on the real or imagined consciousnesses” (4). “A Boring Story” most forcefully explores the nuances of the experience of the distressed and disintegrating professor, even to the point of foregrounding the horrible lack of genuine events in his life in comparison with the dull, iterative, and meaningless quasi-events.

It is obvious then that “A Boring Story” distorts the clear sequence of events and makes understanding the temporal structure complicated or partly impossible; nevertheless, this is done for the purpose of foregrounding the disruption in the professor's life and to convey the experience of the total disintegration of his life. Despite all the efforts needed in capturing the event sequencing, the short story arguably represents a high level of prototypical narrativity, but unevenly in terms of the basic elements.

This uneven narrativity may solve some problems; it certainly creates new ones. Rather than reasoning that Herman's model has now neatly solved our problem between the contrasting 
interpretations between the classical approach and Fludernik's natural narratology, I propose that the model introduces a new kind of instability in appraising narrativity. If I read Herman correctly, he does not suggest any mediating process, co-dependency or mechanism able to harmonize the potentially contrasting effects of his four elements of narrativity. It is therefore credible to presume that we can have narratives that expose high narrativity in terms of some elements (say, three and four) while being resistant, ambiguous and highly static in terms of other elements (say, second element, the sequence of events). Different narratives and different narrative genres may therefore privilege diverse elements and diverse combinations. On a primary theoretical level this idea is not hard to accept, at least intuitively. However, if we accept it, a further problem arises: what is left of the concept of narrativity itself, if its criteria changes from narrative to narrative? If we have arrived at a point where it is inadequate to characterize texts in terms of 'dense' or 'weak' narrativity; we should also have more particularized terms for characterizing different ways of departing from the prototypical narrativity.

In what follows, I will leave Chekhov and reflect on the issue of uneven narrativity with the help of a more recent author, W. G. Sebald, and his novel The Rings of Saturn (1995). My proposal is to turn the idea of uneven narrativity into a resource of reading instead of seeing it as a mere deficit of theory.

\section{Sebald's Travels}

Sebald's novel The Rings of Saturn ${ }^{2}$ develops the tensions between the basic elements of narrative to an extreme and thus offers a prime case in point to elaborate my theme. So prominent is Sebald's resistance to clear and conventional plot-lines that Kathy Behrend discusses him as an example of anti-narrativity, drawing the idea from Galen Strawson's essay “Against Narrativity.” Sebald's prose, however, is far too complex to fit into such clear-cut frames as proposed by Strawson. In Strawson's theory, people can be divided, even genetically, into the "diachronic/narrative” and "non-diachronic/episodic" personalities. Therefore, Strawson suggests, these "Diachronics and Episodics are likely to misunderstand one another badly” (431). Against this rather rigid theory of

\footnotetext{
${ }^{2}$ Born in Germany, Sebald (1944-2001) wrote his books in German. Nevertheless, from the 1960s he resided in England where he taught German literature. I believe that he was able to monitor the English translations adequately, and used primarily two excellent translators, Michael Hulse and Anthea Bell.
} 
character, I suggest that both "diacronicity" (thinking of oneself in terms of a temporally continuing and essentially the same person over time) and "episodicality" (thinking of oneself as a qualitatively different person than the past self) are culturally widely shared resources that competent adults use interchangeably in different situations. Sebald is a prime example in confusing Strawson's clear categories: Sebald is keenly interested in his own and the collective past, his travel narratives cannot be characterized in simple terms of "form-finding," yet he insists on being a storyteller.

For Strawson, "the paradigm of a narrative is a conventional story told in words." Thus he takes "the term to attribute-at the very least—a certain developmental and hence temporal unity or coherence to the things to which it is standardly applied — lives, parts of lives, pieces of writing” (439). This definition already posits both Chekhov and Sebald outside the sphere of narrativity. The narrow definition leaves too much on the non-narrative side. Therefore his claim that episodic thinking falls outside narrativity is not convincing. Following his normative definition of narrative, Strawson portrays the philosophers Plato, St. Augustine, Martin Heidegger and Thomas Nagel as typical cases of Narrativity — while such novelists as Marcel Proust, Iris Murdoch, Virginia Woolf and Stendhal belong to his Episodic personalities (432). Thus it appears that some of the best narratives are written by individuals who are unable to understand narrative personality due to their episodic outlook. The way out of such an impasse requires the rejection of an overly homogenous and essentialist understanding of narrative. James Phelan, for example, points out one key aspect of narrative diversity when he says:

At one end of a wide spectrum are narratives offering thick descriptions....At the other end of the spectrum are narratives that stand above the myriad details of experience, using the mode's finite means in the service of abstraction and simplification, eschewing thick description for the synoptic view (girl meets boy; girl loses boy; girl reunites with boy). (167)

Sebald and Chekhov are situated mostly at the former end of the spectrum, while Strawson prefers to think of narratives only in terms of the other end, by way of simplification and form-giving. The idea of uneven narrativity allows for elaborating the diversity of narratives and narrativity further. Following the idea of this article I suggest that the narrativity of Sebald's novel is uneven as regards the basic elements of narrativity, as well as in terms of the levels of the narrative organization. 
The frame of The Rings comes from the travelogue, as is usually the case in Sebald's work. “The journey is universally recognized as a narrative in our culture,” writes Kai Mikkonen (286). More specifically, Mikkonen suggests that the "notion of travel ascribes and tends to increase narrativity” (288). Nevertheless, travels are not one and the same: the quest (e.g. Proppian wonder tales), the pilgrimage and odyssey set the relationships between writing, reading and traveling differently. Sebald's writing, in particular in The Rings, does not foreground causally linked events or a traveler's adventures.

The frame of travelogue provides the texts with a meandering structure of sensing, thinking and talking, and essayistic meandering is exactly what Sebald does with the material of his travels: “At the end of September 1970, shortly before I took up my position in Norwich, I drove out to Hingham with Clara [Sebald's partner] in search of somewhere to live” (Emigrants 3); “In October 1980 I travelled from England, where I had then been living for nearly twenty-five years in a county which was almost always under grey skies, to Vienna...” (Vertigo 33); “In August 1992, when the dog days were drawing to an end, I set off to walk the county of Suffolk, in the hope of dispelling the emptiness that takes hold of me whenever I have completed a long stint of work” (Rings 3). All these beginnings locate the speaker, the exact point of time, and the rationale motivating the trip. All of these equally point in the direction of non-fiction, to something really experienced and witnessed by Sebald. Nevertheless, the beginning of Austerlitz, without giving an exact date, begins with a similar documentary reference to time, intention, traveling, and the unsettling sense of 'feeling unwell' (Austerlitz 1). Most confusingly, the narratorial voice of Austerlitz already sounds familiar from the more documentary books (“a tone of inconsolable disarray,” as Brockmeier [347] has it). Note also the strong bodily presence of the author — his situatedness — while readers are invited to acknowledge the sensations of illness and awkwardness right at the outset of most of these journeys, and explicitly so in The Rings.

The frame of travelogue, of course, does not guarantee any degree of non-fictionality, as Austerlitz indicates. In Vertigo, the emphasis is on the arts (e.g., Stendhal, Casanova, Kafka); in Austerlitz the emphasis is mostly on architecture, memory, and the Holocaust; in The Rings, on the most diverse representations of destruction. A novel which begins like a realistic account of a walking trip, soon turns to discuss Rembrandt's The Anatomy Lesson in a learned manner; visits the coastline near the Battle of Sole Bay (1672), during which, “on the Royal James alone, which was set aflame by a fireship, nearly half the thousand-strong crew perished” (Rings 77), and turns to 
discuss the genocides in the Congo and Nazi Germany. On one level, the novel is almost a catalog of incomprehensible human cruelty, waste, and destruction in modern times. The disparity between the frame and content is enormous: a stroll in East-Anglia, in a perfectly peaceful landscape, invites the whole array of modern atrocities to march in, one after the other, before the eyes of the reader. After all, the troubled times of the British Empire are not so far away, and the problems of destruction do not entirely hide on the other side of the German Sea, as the author prefers to call the North Sea. As Murray Baumgarten says about The Emigrants, "his journey becomes a paradoxical pilgrimage into historical memory — into a set of cultural memories apparently erased, deleted from the contemporary European landscape” (271).

The structure of Sebald's novel is complex enough to frustrate any attempt at analyzing it in any systematic way; nonetheless, I try to suggest a rough draft for further discussion. On the embedding level, in the travelogue, very little seems to happen in this novel. In Vertigo, by contrast, the traveler is constantly pained by deep anguish, nearly paranoia, and he has to escape from cities and revise his plans time after time-while the subject of the book is indeed Franz Kafka. However, in The Rings the frame primarily offers a possibility to move on swiftly in essayistic investigations into a kaleidoscope of themes (e.g., Rembrandt's painting, the fishing industry, the life and fate of Roger Casement). The frame of travel, in other words, seems above all to allow a rich variety of thematic combinations. Travelogue foregrounds space and renders the complication of the temporal structure easier.

One of the most creative shifts takes place in introducing the case of the Congo: "On the second evening of my stay in Southwold, after the late news, the BBC broadcasted a documentary about Roger Casement, who was executed for high treason” (Rings 103). The traveler falls asleep, and has later to work hard to collect the details from various archives. Finally the narrator reveals how Casement meets Konrad Korzeniowski-Joseph Conrad-in the Congo, then takes a few steps backwards in the chronology to the time of Conrad's father as an unfortunate anarchist resisting Russian rule in Poland, a stance which leads to his deportation into a miserable Russian camp and premature death; then again the story proceeds with Conrad's own adventurous life as a sailor. Note also, that there is no causal link between the traveler's stay in Southwold, the BBC broadcasting the program on Casement, nor the traveler’s falling asleep during the broadcast. They are chance occurrences made possible, for example, by the fact that the narrator-traveler does not stay in a tent or spend the evening in a local pub conversing with local characters. 
The travels finally funnel Korzeniowski into the Congo and to the scenery of Heart of Darkness, to his meeting with Casement as the probably only representative of the British Empire in the Congo reporting honestly on the ongoing massacre of the original population. Now the narration leaves Conrad and follows Casement's story on to his eventual hanging on the strength of an alleged military treason, when he supported his Irish cause during the Great War (Sebald resorts to this old term for the First World War). In the frame narrative, the author watches television and falls asleep; whereas in the following storytelling much grimmer episodes come to the foreground. The high narrativity of Casement's story, his tragedy, I should add, is difficult to refute without subscribing to an overly simplistic understanding of narrative. Temporality is there, as is the world-making and world destruction, and the experientiality of the story is not hidden. As in "A Boring Story," the reader has problems following the chronology of the frame narrative and, sometimes, of the embedded stories too. This is due to the fact that Sebald's narrator often tends to blur the point of transition from one story to another, as if preferring to change tracks in the middle of his notoriously long subordinate clauses.

The frame story of travel itself seems not, in this novel, to contain much in terms of dramatic settings, development, or emplotment. The narrating 'I', virtually indistinguishable from Sebald, walks in Suffolk, visits places and meets people, until he phones home, and Clara comes to fetch him from a pub called Mermaid. To add a strong documentary flavor, a genuine reality effect indeed, there is a photograph portraying Sebald resting against a huge Lebanese cedar in Ditchingham Park (Rings 263). Unfortunately, as the reader soon learns, the picture was taken ten years previously, and a hurricane had since destroyed the whole park. The photo is, after all, a visual document — if not of a Paradise Lost — then of the destruction of the old tree stand in Suffolk due to insufficient planting, raging plant diseases and natural catastrophes.

\section{Story and Discourse}

In the final chapter of the novel, while discussing in an essayistic style Sir Thomas Browne and silk worm farming in Britain and Nazi Germany, the narrator finally arrives at the time of writing (the $13^{\text {th }}$ of April 1995; Rings 294), only to go immediately ahead by accounting some peculiar coincidences in his own family histories. Arriving at home has thus neither finished the story, nor is the end of the journey any proper answer to the instabilities introduced earlier-in any other sense 
than that the author has arrived home with material for his further literary work. The frame is thus a strong case in point of what Brian McHale has termed ‘weak narrativity’ (McHale; Tammi).

In addition to this weak narrativity, there is also an aspect we may arguably call 'resistance to story and sequence.' By 'resistance to story’ I mean narrative strategy which does not foreground the events of the past, or the construction of a distinct and sequentially clear storyworld, but rather one which privileges the moment of telling, the narrative discourse and reflection (Baumgarten 278) over all dramatic sequences of events in the past. In so doing, Sebald advances the events of the story until they finally merge together with the moment of crafting the narrative discourse.

Comparing the novel to more traditional travelogues may clarify Sebald’s narration. Even though there is the central character, 'I,' his acts and features remain astoundingly vague and in the background. For sure, the traveler observes, experiences and thinks. But even then the reader must be awake-is it truly the traveler who thinks, or is it the narrator of the novel who does the reflecting while drafting the manuscript, or a merger of these instances? Unlike some other travelogues, the frame narrative is not about visiting highly exoticized or dramatic resorts, which would imprint their deep impressions on the character. The traveler visits atrocities of all kinds, so much is true, and registers them. Yet again, for example the scenery of the Battle of Sole Bay is not exactly visible during a walk on the East Coast of England; it is only by visiting museums, consulting history books and studying paintings that Sebald is able to construe the experience and reflection upon the sea battle. Therefore the paintings to reconsider, therefore the afterthoughts about the number of lost of men, exceeding the population of most cities of the time.

A rough outline of the structure might look something like this, though it must be noted that this representation of the embeddings is analytical, for the text can either continue on one level or jump to any other level without a clear warning:

Frame: travelogue (weak narrativity)

Investigations and essays into the themes of the novel (partly anti-narrative)

Images (narrative and/or anti-narrative)

Intensive storytelling (strong narrativity)

On the frame level, and through the concomitant reflections, the author challenges the reader's capacities to follow the narrative and the course of events. Here the novel often hovers between 
weak narrativity and anti-narrative. In contrast to this weak narrativity on the frame level, the embedded intensive story-telling is characterized by strong narrativity. The mysterious story about Major George Wyndham Le Strange (Rings 59-64) is a good case in point. We learn that Le Strange had "served in the anti-tank regiment that liberated the camp at Bergen-Belsen on the $14^{\text {th }}$ of April 1945.” After the war he returns to manage his great uncle’s estates in Suffolk, until he begins to withdraw from social contacts in the mid-1950s. After his death, he left his property of seven million pounds to his housekeeper. The role of the housekeeper was quite particular:

According to the newspaper report, Le Strange employed this housekeeper, a simple young woman from Beccles by the name of Florence Barnes, on the explicit condition that she take the meals she prepared together with him, but in absolute silence. (62)

According to the story, Le Strange gradually discharged his whole household staff, in order to live in silence with his housekeeper. Sebald does not merely recount this odd story; he also adds a copy of the newspaper clipping which launched his interest in Le Strange’s story. Sebald does not offer any explicit textual interpretation as a closure; instead, he provides a double-page photo of a forest full of dead bodies in the middle of the story. The image has no comments or subtitles at all, yet the reader tends to think of it as an image from Bergen-Belsen. Despite the weak narrativity on the frame level, these kinds of moments in Sebald's storytelling compellingly exhibit dense and particular narrativity. It is noteworthy that the stories of Roger Casement, Major Le Strange as well as many stories told by Jacques Austerlitz are indeed prototypical narratives; compelling, temporally ordered, surprising, touching and perplexing (cf. Sternberg 640-48). Sebald crafted them to be memorable and recognizable.

\section{The Role of Storytelling}

Structuralist narratology tends to focus on separate, individual narratives, which, as it was presumed, illustrated and instantiated the deep level of permanent narrative grammar (and possibly for this reason, were ideologically determined and suspect) (Prince). Narratives were worlds apart, closed and finished; therefore they had a strong closure and the tendency to follow the strict sequence of beginning, middle, and end. Many studies on oral, everyday storytelling have recently 
criticized this rigid model (Georgakopoulou; Hyvärinen et al.; Langellier and Peterson; Ochs and Capps). Elinor Ochs and Lisa Capps, in particular, argue that in conversational storytelling descriptions of previous narratives are questioned, chronologies regularly invite clarifications, evaluations are challenged; and explanations can lead to continued speculations about their adequacy (18-20).

Structuralist narratology typically freezes the social process of storytelling by investigating narratives in separation, or worse, understands even storytelling merely from the perspective of multiplying the number of entirely separate narratives. Strawson, for example, frames storytelling as a perpetual monologue-an individual telling his or her story once and again. Hayden White, in The Fiction of Narrative, similarly sees storytelling as a characteristic of text, in posing his old question in a new form "whether storytelling-or what we may call, more technically, the narrative mode of discourse” (273). For White, storytelling is still a part of the language system, while Mikhail Bakhtin's theory of language helps to locate it within the use of language. "Every utterance must be regarded primarily as a response to preceding utterances of the given sphere,” Bakhtin says in Speech Genres \& Other Late Essays, therefore "each utterance is filled with various kinds of responsive reactions to other utterances of the given sphere of speech communication” (91). Utterance, for Bakhtin, is a singular speech event by one speaker from its beginning to end, thus The Rings is one utterance by Sebald and construed by compiling many different and potentially competing sub-utterances. My concept of storytelling, then, comprises this exchange of (narrative) utterance with all kinds of responses and not only the characteristics of a single utterance.

Phelan, by following Bakhtin’s idea, recalls the socio-political aspect that narratives are presented “in contest” during storytelling (168). The study of Sebald's work, in accordance with my analysis, requires the recognition of socio-political storytelling as an analytic tool in the study of fiction, as it already has been in the study of everyday conversations. Sebald combines, as I have argued, weak and resistant narrativity on the frame level and intensive narrativity on the level of embedded storytelling. The whole novel is only barely or fragmentarily $a$ narrative, while the storytelling keeps the narrativity intensive and the narrative closure at bay.

Briefly, storytelling is a social and political practice, and is therefore not properly visible within the structuralist model. Any closure, any end of story can be re-questioned, augmented or contradicted by the stories that follow. From this perspective of cultural storytelling, Sebald's novel has an episodic and fragmented structure, where the images and different stories comment upon 
each other, without one, covering meaning or closure to appear at the end of the narrative. The book is, at the same time, full of captivating sub-stories as parts of the continuous storytelling, and still without the form of closed, conventional narrative.

Sebald adds to difficulties of reception by employing his exceptionally long paragraphs, often continuing page after page. An entirely new storyline can begin right in the middle of a long paragraph. On page 119, for example, begins the last paragraph on Conrad’s story. Two pages later, Sebald is ready to leave Conrad and briefly tell about Joseph Loewy, “an uncle of Franz Kafka” (Rings 121). Using a photograph as a further cue, he soon moves to the narrator's own recollections, remembering how "to this day one sees in Belgium a distinctive ugliness" (122). In a short while "the so-called historical memorial site of the Battle of Waterloo" (123) is presented as "the very definition of Belgian ugliness.” Out of the “objective” narration of Conrad’s story, the paragraph had moved into an essay and to personal memories of the narrator, ending with a "hunchbacked pensioner,” seen by the narrator in a Belgian restaurant (126-27). On page 5 he starts telling about his recently deceased colleague Michal Parkinson, while at the end of the paragraph, on page 17, he has just discussed Rembrandt's The Anatomy Lesson.

Some structuralist theories would explicitly disregard Sebald’s narration qua narration. Emile Benveniste, Gérard Genette and Hayden White contrasted ‘narrative’ and ‘discourse’ linguistically. By taking his examples from the $19^{\text {th }}$ Century realistic novel and the historiography of the same period, Benveniste outlined a conception of purely chronological narrative of the past world. He argued that a whole array of linguistic forms such as 'I,' 'you,' and other deictic references to the writing moment were strictly excluded from the 'narrative' mode, whereas the French form of the aorist was typical for this narrative 'in the strict sense.' “The tenses of a French verb are not employed as members of a single system; they are distributed in two systems which are distinct and complementary,” Benveniste argues (206). The "historical utterance” that narrates the past has a particular form.

It is sufficient and necessary that the author remain faithful to his historical purpose and that he proscribe everything that is alien to the narration of events (discourse, reflections, comparisons). As a matter of fact, there is then no longer even a narrator. The events are set forth chronologically, as they occurred. No one speaks here; the events seem to narrate 
themselves. The fundamental tense is the aorist, which is the tense of the event outside the person of a narrator. (208; my emphasis)

Genette remarks that Benveniste includes "in the category of discourse all that Aristotle calls direct imitation and which actually consists (at least in its verbal portion) in the discourse attributed by the poet or storyteller to one of the characters" ("Boundaries” 8). The examples Benveniste and Genette offer come from the historian Glotz and from Balzac. "In discourse, someone speaks and his situation in the very act of speaking is the focus of the most important signification. In narrative, as Benveniste insists, no one speaks, in the sense that at no moment do we have to ask 'Who is speaking?' 'Where?' 'When?' etc., in order to receive fully the meaning of the text,' argues Genette (10). All kinds of first-person narration, of course, here falls within 'discourse,' but also such thirdperson forms that elucidate the narrator. Sebald uses such 'discourse' systematically throughout Austerlitz: "Towards the end of the nineteenth century, Austerlitz began, in reply to my question..." (9; my emphasis). What is currently, after Labov and Waletzky, discussed in terms of oral storytelling could only be understood in terms of discourse in the terminology of Benveniste. Genette even suggests a hierarchy of "naturalness" between these modes:

Actually, discourse has no purity to preserve because it is the natural mode of language, the broadest and most universal mode, by definition open to all forms. On the contrary, narrative is a particular mode, marked and defined by a certain number of exclusions and restrictive conditions (no present tense, no first person, etc.) Discourse can "narrate" without ceasing to be discourse. Narrative can’t “discourse” without betraying itself. (“Boundaries" 11)

In his Narrative Discourse, Genette has already rejected the idea of dividing texts into discourse and narrative (or story). As he says, "the level of narrative discourse is the only one directly available to textual analysis” (27), meaning that the earlier distinction no longer applies. The mere title of the English translation blends these earlier separate worlds. Story refers now to "the succession of events...that are the subjects of the discourse," not to a purified and particular linguistic form (25). Discourse, reflections and comparisons are of course recurrent and predominant features in Sebald's prose. Instead of metaphor, Sebald prefers to use the open comparison provided by simile 
(“It is as if...”), comparing all the time what he sees with something known from his past or literature. Chronology he destroys systematically and in the most innovative ways; and it is perfectly clear that someone is indeed speaking in his text. By applying the concept of narrative, White suggests, Sebald's novel is not a narrative at all but through and through a discourse. Yet in those sections I have called "storytelling," when Sebald self-consciously enters the field of narrative contestation, he temporarily resorts to the particular linguistic form Benveniste and Genette discuss in terms of the "objectivity of narrative” (Genette, “Boundaries” 8).

Sebald's novel emphatically foregrounds the 'I,' both as the character walking in Suffolk and as the author finishing his book “[on] 13th of April, 1995” (Rings 294). The naming of the date when Sebald is able to "bring these notes to a conclusion" adds a new level of fusion. The final day of writing the novel is, at the same time, transported into the storyworld, introducing one more ending for the story. A reader who would concentrate only on the events of the past, following a presumed sequence, would be frustrated before finishing the first page. Almost immediately after outlining his mental state at the beginning of the journey, Sebald continues: "At all events, in retrospect I became preoccupied not only with the unaccustomed sense of freedom but also with the paralyzing horror that had come over me at various times when confronted with the traces of destruction” (3; my emphasis). Sebald does not linger in the story time ('narrative,' to use Benveniste's and White's language) and past history even for a page, but draws his afterthoughts, various other points of time, and narrative discourse immediately in front of the reader, and keeps traveling back and forth in time. No-one can be fooled into believing that the events 'narrate themselves.'

Lydia Davis' novel The End of the Story (1995) works systematically with a similar blending of story-time and discourse. First the female narrator is telling about the end of a love story, but this is increasingly interrupted by a story about writing a novel on the end of a love story — the novel the reader is reading. The problems of memory, reliability and endless editing intervene over the course of the "original” story, and actions taken within the relationship and actions taken as regards the manuscript end up being on an equal level.

Nevertheless, in contrast to what I have argued earlier, there is after all something dramatic taking place on the level of the frame narrative in The Rings of Saturn. After noticing the 'paralyzing' impact that the images of destruction have on him, the author continues: “...a year after to the day after I began my tour, I was taken into hospital in Norwich in a state of almost total 
immobility. It was then I began in my thoughts to write these pages” (3-4). In Aristotelian terms, the sequence might-ironically_-be outlined as follows: beginning-end-middle-end-end (middle again). The travel story, in other words, is over, firstly, when the journey is over (Rings 261); secondly, when the author is admitted into hospital and decides to write about the journey (4-5); and, thirdly, when he finishes writing the book (294).

\section{At the Limits of Narrative}

David Herman's version of postclassical narratology and prototypical narrativity, portrayed above, has solved some problems in freeing the concept of narrativity from the exclusive level of plotline, conflict, and disruption. In doing so, it brought in new kinds of contradictions. For example, the frame narrative of The Rings displays rather weak narrativity when analyzed from the perspective of the sequence of events, conflict, and disruption. However, if we read the essayistic and visual expanses as explorations of the experience, the narrative, as a whole, exhibits a very high level of narrativity.

The travelogue enables a personal and embodied approach to Sebald's investigations on human destruction; essays, images and particular stories resist the dominance of one story, one closure, and one route of reading. Brian Richardson argues in his Unlikely Stories, while discussing an example offered by Shlomith Rimmon-Kenan, that the "absence of causal connection makes it appear non-narrative, if not nonsense, as the author is ready enough to admit” (94). It is not difficult to agree with Richardson that "Little Red Riding-Hood strays into the forest and then Pip aids the runaway convict” appears to be non-narrative, but it may be a fallacious step to expect something as particular as causal connection for a remedy. For most readers, there is no relevant thematic connection between the two sentences in the example. They simply seem to open two independent storyworlds without any relevant interconnections. "Contrary to what Richardson argues,” says Mikkonen, "even if we agree with him that causality is a central aspect in narrative experience, it is not always decisive for considering something a narrative” (293).

The causal connection runs into severe problems with chance, contingency and Herman's third element of world-disruption. Narratives are vitally about trying to understand contingency, and one standard definition of contingency is "not causally determined” (Bruner; Hutto; Morson). Noël Carroll’s more specified proposal of “narrative connection” seems to discriminate both against 
nonsensical stories as the overly deterministic weight of causal connection. For Carroll, the earlier events of the story need not causally determine or cause the later events, but the latter events need to make sense within the worlds opened by the earlier events-and the first events need to be relevant after the final ones. In the case of The Rings, for example, there is no obvious causal connection between "I" taking a walking trip in East-Anglia, and his falling ill the year after the walk. Yet falling ill is entirely possible, and it is possible to make it relevant in evaluation of the journey, as the author does. "In the second half of the 1960s I travelled repeatedly from England to Belgium,” writes Sebald at the beginning of Austerlitz. This event has no causal connection with the "I" actually meeting Austerlitz at Antwerp Central Station. Nevertheless it makes such a meeting possible and understandable.

As for narrative, it is obvious that Sebald's novel as a whole is rather a study of the limits and merits of narrative than 'a' narrative. The author is able to mobilize, in the same novel, the resources of 'weak narrativity' on the level of frame story; resistance to narrativity by employing the forms of essay and competing narratives, as well as powerful narrativity in telling particular stories about disappeared towns, disappearing fishes, perished men, and persecuted people. Sometimes Sebald is miles away from the prototypical narrativity, stepping freely outside of the whole text type in essayistic explorations, and then suddenly telling a truly prototypical story with the particularized course of events, dramatic disruptions and instabilities, and showing the suffering consciousnesses. One of his particular gifts as storyteller, indeed, is his proficiency in diversion. The next path taken by the story is as unheralded as the course of his travels.

My own journey to the weak and uneven narrativity, anti-narrativity and resistance to sequence and story, can now be summarized into the following theses:

(1) Narrativity is always a matter of degree (Abbott; Fludernik; Herman);

(2) The character of narrativity has changed since the experiential turn has challenged the role of sequence of events as the key denominator of narrativity (Fludernik; Herman; Hyvärinen et al.; Patterson; Squire)

(3) Narrativity is not a homogeneous phenomenon. A key consequence of David Herman's prototypical model is to see four relatively independent aspects of narrativity.

(4) Narrativity can exist and often exists unevenly, in particular as regards the aspects of event sequencing, world-making and destruction, and experientiality. 
(5) The anti-narrative argument (Behrendt; Strawson) remains unspecific as far as the criteria of narrativity are not properly specified and if the criteria differ dramatically from those used in recent theories of narrative, including those of post-classical narratology.

(6) Complex narrative texts, such as novels, films, and entire life historical interviews, can exhibit narrativity unevenly. Uneven narrativity should be recognized both in terms of i) the different levels or criteria of narrativity; and ii) in terms different levels or sections of the text. As Sebald's The Rings of Saturn demonstrates, one level of the novel can resist narrativity (as clear sequencing of events) while other levels (embedded storytelling) signify high and prototypical narrativity.

(7) 'Weak narrativity,' finally, can also refer to different versions of uneven narrativity; including both causally over-determined and overly vague representations. ${ }^{3}$

\section{Works Cited}

Abbott, H. Porter. The Cambridge Introduction to Narrative. Cambridge: Cambridge UP, 2002.

Bakhtin, M. M. Speech Genres and Other Late Essays. Trans. Vern W. McGee. Austin: Texas UP, 1986.

Baumgarten, Murray. “'Not Knowing What I Should Think’: The Landscape of Postmemory in W. G. Sebald's The Emigrants.” Partial Answers 5.2 (2007): 267-87.

Behrendt, Kathy. "Scraping Down the Past: Memory and Amnesia in W. G. Sebald’s AntiNarrative.” Philosophy and Literature 34.2 (2010): 394-408.

Benveniste, Emile. Problems in General Linguistics. 1966. Trans. Mary Elizabeth Meek. Miami Linguistics Series vol. 8. Coral Gables: U of Miami P, 1971.

Brockmeier, Jens. “Austerlitz’s Memory.” Partial Answers 6.2 (2008): 347-67.

Bruner, Jerome. Acts of Meaning. Cambridge: Harvard UP, 1990.

Chekhov, Anton. “A Boring Story.” 1889. Trans. Richard Pevear and Larissa Volokhonsky. Stories by Anton Chekhov. New York: Bantam Books, 2000. 55-107.

Davis, Lydia. The End of the Story. New York: Picador, 1995.

\footnotetext{
${ }^{3}$ Earlier versions of this article have been presented at the conferences Arts, Violence, and Imagination, London, October 23-25, 2009, and at the International Narrative Conference, Cleveland, April 8-11, 2010. I am grateful to the participants for their comments. The research for this article was done in the Academy of Finland research project 'The Conceptual History of Narrative' (SA 111743).
} 
Fludernik, Monika. Towards a 'Natural' Narratology. London and New York: Routledge, 1996.

Forster, E. M. Aspects of the Novel. 1927. London: Edward Arnold, 1974.

Genette, Gérard. “Boundaries of Narrative.” New Literary History 8.1 (1976): 1-13.

—. Narrative Discourse: An Essay in Method. 1972. Trans. Jane E. Lewin. Ithaca: Cornell UP, 1980.

Georgakopoulou, Alexandra. Small Stories, Interaction and Identities. Ed. Michael Bamberg. Amsterdam and Philadelphia: John Benjamins, 2007.

Herman, David. Basic Elements of Narrative. Malden, MA: Wiley-Blackwell, 2009.

Hutto, Daniel D. "The Narrative Practice Hypothesis: Origins and Applications of Folk Psychology.” Narrative and Understanding Persons. Ed. Daniel D. Hutto. Cambridge: Cambridge UP, 2007. 43-68.

Hydén, Lars-Christer. “Identity, Self, Narrative.” Beyond Narrative Coherence. Ed. Matti Hyvärinen et al. Amsterdam: John Benjamins, 2010. 33-48.

Hyvärinen, Matti, et al., eds. Beyond Narrative Coherence. Amsterdam: John Benjamins, 2010.

Labov, William, and Joshua Walezky. 1967. "Narrative Analysis: Oral Versions of Personal Experience.” Journal of Narrative and Life History 7.1-4 (1997): 3-38.

Langellier, Kristin M., and Eric E. Peterson. Storytelling in Daily Life. Philadelphia: Temple UP, 2004.

McHale, Brian. "Weak Narrativity: The Case of Avant-Garde Poetry.” Narrative 9.2 (2001): 16167.

Mikkonen, Kai. “The 'Narrative Is Travel’ Metaphor: Between Spatial Sequence and Open Consequence.” Narrative 15.3 (2007): 286-305.

Morson, Gary Saul. “Contingency and Poetics.” Philosophy and Literature 22.2 (1998): 286-308.

Ochs, Elinor, and Lisa Capps. Living Narrative: Creating Lives in Everyday Storytelling. Cambridge: Harvard UP, 2001.

Patterson, Wendy. "Narratives of Events: Labovian Narrative Analysis and Its Limitations.” Doing Narrative Research. Ed. Molly Andrews, Corinne Squire, and Maria Tamboukou. London: Sage, 2008. 22-40.

Phelan, James. "Narratives in Contest; or, Another Twist in the Narrative Turn.” PMLA 123.1 (2008): 166-75. 
Prince, Gerald. "Narratology and Narratological Analysis.” Journal of Narrative and Life History 7.1-4 (1997): 39-44.

Richardson, Brian. Unlikely Stories: Causality and the Nature of Modern Narrative. Newark: U of Delaware P, 1997.

Squire, Corinne. "Experience-Centred and Culturally-Oriented Approaches to Narrative.” Doing Narrative Research. Ed. Molly Andrews, Corinne Squire, and Maria Tamboukou. London: Sage, 2008. 41-63.

Sebald, W. G. Austerlitz. Trans. Anthea Bell. London: Hamish Hamilton, 2001.

—. Campo Santo. 2005. Trans. Anthea Bell. London: Penguin Books, 2006.

—. The Emigrants. 1993. Trans. Michael Hulse. London: The Harvill Press, 1996.

— - The Rings of Saturn. 1995. Trans. Michael Hulse. London: The Harvill Press, 1998. Vertigo. 1990. Trans. Michael Hulse. London: Harvill Press, 1999.

Sternberg, Meir. "Narrativity: From Objectivist to Functional Paradigm.” Poetics Today 31.3 (2010): 507-659.

Strawson, Galen. “Against Narrativity.” Ratio (New Series) XVII.4 (2004): 428-52.

Tammi, Pekka. “Against Narrative ('A Boring Story').” Partial Answers 4.2 (2006): 19-40.

White, Hayden. "The Value of Narrativity in the Representation of Reality." 1981. The Content of the Form: Narrative Discourse and Historical Representation. Baltimore and London: The Johns Hopkins UP, 1987. 26-57.

White, Hayden. The Fiction of Narrative: Essays on History, Literature, and Theory 1957-2007. Baltimore: The Johns Hopkins UP, 2010. 